\title{
CLINICAL OPPORTUNITIES FOR GERMLINE PHARMACOGENETICS AND MANAGEMENT OF DRUG-DRUG INTERACTIONS IN PATIENTS WITH ADVANCED SOLID CANCERS
}

Tyler Shugg, PharmD, PhD ${ }^{1^{*}}$; Reynold C. Ly, $\mathrm{PhD}^{1^{*}}$; Elizabeth J. Rowe, $\mathrm{PhD}^{1}$; Santosh Philips, $\mathrm{PhD}^{1}$; Mustafa A. Hyder, MD ${ }^{1}$; Milan Radovich, $\mathrm{PhD}^{2}$; Marc B. Rosenman, $\mathrm{MD}^{3}$; Victoria M. Pratt, $\mathrm{PhD}^{4}$; John T. Callaghan, MD, $\mathrm{PhD}^{1,5}$; Zeruesenay Desta, $\mathrm{PhD}^{1}$; Bryan P. Schneider, $\mathrm{MD}^{2}$; Todd C. Skaar, $\mathrm{PhD}^{1}$

${ }^{1}$ Division of Clinical Pharmacology, Department of Medicine, Indiana University School of Medicine, Indianapolis, IN; ${ }^{2}$ Division of Hematology/Oncology, Department of Medicine, Indiana University School of Medicine, Indianapolis, IN; ${ }^{3}$ Ann \& Robert H. Lurie Children's Hospital of Chicago and Institute of Public Health, Feinberg School of Medicine, Northwestern University, Chicago, IL; ${ }^{4}$ Department of Medical and Molecular Genetics, Indiana University School of Medicine, Indianapolis, IN; ${ }^{5}$ Department of Pharmacology and Toxicology, Indiana University School of Medicine, Indianapolis, IN

*These authors contributed equally to this work

\section{Acknowledgement of Research Support:}

This research was supported by NIGMS R35GM131812 (awarded to TCS) and funds from the Indiana University Grand Challenge to support the institutional Precision Health Initiative (provides salary and research support to TS, RCL, EJR, SP, MR, BPS, and TCS).

\section{Corresponding Author:}

Todd C. Skaar, PhD

Professor of Medicine

Division of Clinical Pharmacology, Department of Medicine

Indiana University School of Medicine

Research II, E419

950 W Walnut St.

Indianapolis, IN 46202

Email: tskaar@iu.edu

Phone: 317-274-2821

Running Head: Opportunities for precision medicine in advanced cancer patients

Where Presented: Presented as a virtual poster at the 2021 annual meeting of the American Society for Clinical Pharmacology and Therapeutics 
medRxiv preprint doi: https://doi.org/10.1101/2021.08.23.21262496; this version posted August 30, 2021. The copyright holder for this preprint (which was not certified by peer review) is the author/funder, who has granted medRxiv a license to display the preprint in perpetuity.

All rights reserved. No reuse allowed without permission.

47 ABSTRACT

PURPOSE: Precision medicine approaches, including germline pharmacogenetics (PGx) and management of drug-drug interactions (DDIs), are likely to benefit advanced cancer patients who are frequently prescribed multiple concomitant medications to treat cancer and associated conditions. Our objective was to assess the potential opportunities for PGx and DDI management within a cohort of adults with advanced cancer.

PATIENTS AND METHODS: Medication data were collected from the electronic health records (EHRs) for 481 subjects since their first cancer diagnosis. All subjects were genotyped for variants with clinically actionable recommendations in Clinical Pharmacogenetics Implementation Consortium (CPIC) guidelines for 13 pharmacogenes. DDIs were defined as concomitant prescription of strong inhibitors or inducers with sensitive substrates of the same drug-metabolizing enzyme and were assessed for six major cytochrome P450 (CYP) enzymes.

RESULTS: Approximately $60 \%$ of subjects were prescribed at least one medication with CPIC recommendations, and $\sim 14 \%$ of subjects had an instance for actionable PGx, defined as prescription of a drug in a subject with an actionable genotype. The overall subject-level prevalence of DDIs and serious DDIs were $50.3 \%$ and $34.8 \%$, respectively. Serious DDIs were most common for CYP3A, CYP2D6, and CYP2C19, occurring in 24.9\%, 16.8\%, and $11.7 \%$ of subjects, respectively. When assessing PGx and DDIs together, $40 \%$ of subjects had at least one opportunity for a precision medicine-based intervention and $\sim 98 \%$ of subjects had an actionable phenotype for at least one CYP enzyme.

67 CONCLUSION: Our findings demonstrate numerous clinical opportunities for germline PGx and DDI management in adults with advanced cancer. 
medRxiv preprint doi: https://doi.org/10.1101/2021.08.23.21262496; this version posted August 30, 2021. The copyright holder for this preprint (which was not certified by peer review) is the author/funder, who has granted medRxiv a license to display the preprint in perpetuity.

All rights reserved. No reuse allowed without permission.

\section{INTRODUCTION}

Pharmacogenetics (PGx) and management of drug-drug interactions (DDIs) are two aspects of precision medicine that have the potential to optimize medication therapy in oncology and other therapeutic disciplines. PGx-guided approaches have been shown to enhance drug efficacy and safety, including results from prospective clinical trials that have demonstrated the potential for PGx to improve drug safety. ${ }^{1-3}$ Accordingly, the U.S. Food and Drug Administration (FDA) currently includes PGx information within the labels for nearly 300 medications. ${ }^{4}$ Moreover, clinical practice guidelines that include PGx-guided recommendations have been published by the Clinical Pharmacogenetics Implementation Consortium (CPIC) and prominent discipline-specific professional organizations (e.g., the National Comprehensive Cancer Network) for over 100 medications. ${ }^{5,6}$ Similarly, DDIs are known to contribute to adverse drug events, ${ }^{7,8}$ and strategies to manage DDIs have been shown to improve patient outcomes. ${ }^{9}$ Given their important clinical implications, DDIs constitute a major consideration both during drug development and in clinical medicine, and recommendations to manage DDIs are therefore included both in FDA drug development guidance to industry ${ }^{10}$ and in numerous clinical practice guidelines. ${ }^{11,12}$

The clinical utility of precision medicine is expected to be especially high for patients with advanced cancer given that drug therapy is commonly used not only to treat cancer, but also to manage both cancer treatment-related adverse events (e.g., nausea and vomiting) and comorbid conditions associated with cancer (e.g., psychiatric conditions and pain syndromes). As a result, polypharmacy, typically defined as the concomitant use of 5 or more drugs, is exceedingly common in advanced cancer patients. ${ }^{13}$ Polypharmacy carries an increased risk for DDIs, ${ }^{14}$ and, predictably, multiple investigations have identified serious DDIs in advanced cancer that impact patient outcomes. ${ }^{15}$ PGx-guided approaches also offer the ability to optimize 
therapy for numerous anticancer medications based on somatic and germline genetic biomarkers.

96 While molecular tumor boards have effectively harnessed somatic genome-guided treatment

97 approaches to improve patient outcomes, ${ }^{16}$ germline PGx biomarkers can enhance medication

98 safety with agents such as fluoropyrimidine and thiopurine chemotherapies. ${ }^{17,18}$ Additionally,

99 PGx-guided approaches have been shown to enhance both efficacy and safety of selective

100 serotonin reuptake inhibitors (SSRIs), tricyclic antidepressants (TCAs), and opioid analgesics

101 that are often prescribed for comorbid conditions prevalent in cancer. ${ }^{19-21}$ Given these abundant

102 PGx opportunities in cancer patients, it has been suggested that preemptive testing for PGx

103 variants at first cancer diagnosis may be an effective clinical strategy to optimize patient

104 outcomes. ${ }^{22}$ Furthermore, recent advancements in bioinformatics technology have enhanced the

105 feasibility of PGx approaches in cancer through the creation of methods to extract PGx

106 information from existing germline sequencing data generated during the clinical workflow of

107 molecular tumor boards. ${ }^{23,24}$

Although past studies have characterized opportunities for DDI management and PGxguided approaches in patients with advanced cancer, we are not aware of any work that has simultaneously investigated both approaches to provide a comprehensive assessment of the

111 potential for precision medicine. Therefore, the objective of this study was to determine

112 composite opportunities for precision medicine, incorporating both PGx-guided and DDI

113 management strategies, within a cohort of adults with advanced solid cancers. By analyzing the

114 potential for PGx-guided interventions since each subject's respective date of first cancer

115 diagnosis, we also directly investigate the potential clinical utility of preemptively obtaining PGx

116 information when patients are first diagnosed with cancer. 
medRxiv preprint doi: https://doi.org/10.1101/2021.08.23.21262496; this version posted August 30, 2021. The copyright holder for this preprint (which was not certified by peer review) is the author/funder, who has granted medRxiv a license to display the preprint in perpetuity.

All rights reserved. No reuse allowed without permission.

\section{Subject Enrollment and Eligibility}

This study was a retrospective electronic health record (EHR) review and prospective genotyping of eligible patients with solid cancers at Indiana University Health in Indianapolis, Indiana, USA. Subjects were eligible to participate in the study if they 1) had been seen in the Indiana University Health Precision Genomics clinic and enrolled in the accompanying Indiana University Total Cancer Care Protocol (part of the larger Oncology Research Information Exchange Network-wide Total Cancer Care initiative [https://www.oriencancer.org/]) and 2) agreed to submit a blood sample for genotyping. Subjects were enrolled into the study at clinic visits from February 2015 to February 2018. This research protocol, as well as the parent Total Cancer Care Protocol, were approved by Indiana University's Institutional Review Board. All subjects provided written informed consent.

\section{Study Design and Data Collection}

The purpose of this study was to investigate potential opportunities for precision medicine interventions, including PGx and management of DDIs, within a cohort of 481 adults seen at our institutional precision oncology clinic and associated solid tumor board. Demographic and clinical data, including medication prescriptions, were collected from the EHRs of all institutions participating in the Indiana Health Information Exchange, a statewide EHR data repository that includes 38 healthcare systems. Demographic data included age, sex, and race. Clinical data included first oncologic diagnosis and all inpatient and outpatient prescriptions. Genotyping for major pharmacogenes was performed at the College of American Pathologists-accredited Indiana University Pharmacogenomics Laboratory using a laboratorydeveloped assay based on the OpenArray ${ }^{\circledR}$ Platform (ThermoFisher; Waltham, MA). The genes 
medRxiv preprint doi: https://doi.org/10.1101/2021.08.23.21262496; this version posted August 30, 2021. The copyright holder for this preprint (which was not certified by peer review) is the author/funder, who has granted medRxiv a license to display the preprint in perpetuity.

All rights reserved. No reuse allowed without permission.

142 included on the genotyping platform, along with the number of variants tested for each gene,

143 were as follows: $C Y P 2 B 6$ (2), CYP2C19 (6), CYP2C9 (6), CYP2D6 (11, including copy number

144 targeting exon 9), CYP3A4 (2), CYP3A5 (3), CYP4F2 (1), DPYD (2), G6PD (2), IFNL3 (1),

145 SLCOIB1 (2), TPMT (2), and VKORC1 (1). Detailed genotyping methods are provided in the

146 Supplemental Methods, and a complete list of tested variants is shown in Table S1.

147

Medication Inclusion into Precision Medicine Analyses

The PGx analysis included 46 medications with published guidelines as of 09/25/20 by

150 CPIC (full list available in Table S2 and online). ${ }^{5}$ Drugs were considered for inclusion in the

151 DDI analysis if they were listed as substrates, inhibitors, or inducers of CYP2B6, CYP2C19,

152 CYP2C8, CYP2C9, CYP2D6, or CYP3A within 1) the "Clinical substrates," "Clinical

153 inhibitors," or "Clinical inducers" tables of the current version (as of 09/25/20) of the U.S. Food

154 and Drug Administration’s “Drug Development and Drug Interactions: Table of Substrates,

155 Inhibitors and Inducers"25 or 2) the Indiana University School of Medicine's Drug Interactions

156 Flockhart Table ${ }^{\mathrm{TM}} \cdot{ }^{26}$ Medications contained in these resources were reviewed for inclusion into

157 DDI analyses based on the expertise of the study team. The final list of included substrates,

158 inhibitors, and inducers are displayed in Table S2. Medications included in the DDI analysis

159 between tyrosine kinase inhibitors (TKIs) and acid reducers are also listed in Table S2. Within

160 our analyses, acid reducers included antacids, histamine- 2 receptor antagonists (H2RAs), proton

161 pump inhibitors (PPIs), and sucralfate. 
medRxiv preprint doi: https://doi.org/10.1101/2021.08.23.21262496; this version posted August 30, 2021. The copyright holder for this preprint (which was not certified by peer review) is the author/funder, who has granted medRxiv a license to display the preprint in perpetuity.

All rights reserved. No reuse allowed without permission.

Within our analyses, PGx recommendations for drug-gene pairs were classified by genotype-predicted phenotype (e.g., metabolizer status) based on annotations from the Pharmacogenomics Knowledge Base (PharmGKB). Phenotypes were considered actionable if

167 CPIC guidelines recommended a clinical action to manage the drug-gene interaction (see File S1

168 for actionability determinations). Specific clinical actions included adjustment of initial or 169 maintenance dosing, selection of alternative therapy, or performing additional tests to determine enzyme activity.

Using these determinations, we considered genotype-predicted phenotypes as actionable within our phenotype distribution (Table 2) if CPIC guidelines for one or more drug-gene pairs recommended clinical action based on the specified phenotype. For our analyses characterizing

174 the prevalence of actionable PGx opportunities, we only included instances where a medication was prescribed to a subject with a CPIC-defined actionable genotype-predicted phenotype for

176 that same medication (e.g., prescription of clopidogrel in a CYP2C19 poor metabolizer).

\section{DDI Analyses}

DDIs involving CYP enzymes were defined as concomitant prescription of an inhibitor or inducer with a sensitive substrate of the same drug-metabolizing enzyme. To account for

181 temporal delays in CYP induction and de-induction following the onset and offset of CYP

182 inducers, the window for DDIs with co-administered CYP substrates was defined as starting 7

183 days after initiation of inducer therapy and lasting 7 days after termination of inducer therapy.

184 DDIs involving CYP enzymes were analyzed for CYP2B6, CYP2C19, CYP2C8, CYP2C9, 185 CYP2D6, and CYP3A for each patient from their date of first cancer diagnosis until the last date 
medRxiv preprint doi: https://doi.org/10.1101/2021.08.23.21262496; this version posted August 30, 2021. The copyright holder for this preprint (which was not certified by peer review) is the author/funder, who has granted medRxiv a license to display the preprint in perpetuity.

All rights reserved. No reuse allowed without permission.

186

187

of data collection (04/20/20). DDIs were also assessed for concomitant prescription of drug-drug pairs that included TKIs and medications known to reduce gastrointestinal acidity.

Extracted medication data contained the date, time, and location (i.e., whether administered in a medical setting, including outpatient clinics, or whether dispensed from a pharmacy) for each prescription. The days supply for each prescription was conservatively estimated using the following assumptions. For prescriptions administered in a medical setting, the days supply was assumed to be one. For prescriptions dispensed from a pharmacy, the days supply was assumed based on the shortest days supply for indications for which the drug is typically prescribed (see Table $\mathbf{S 3}$ for a complete list of assumed durations for all prescriptions dispensed from a pharmacy). An exception to this method was made for prescriptions dispensed from a pharmacy that were 1) dispensed for at least three consecutive regular intervals (e.g., every 30 days, every 90 days) and 2) written for medications that are commonly used as maintenance therapy for chronic medical conditions (e.g., antihypertensives). For these prescriptions, the patient was assumed to be taking the medication for the entire interval between consecutive prescriptions.

Instances of autoinhibition and autoinduction (i.e., a medication altering its own metabolism upon chronic administration) were not considered as DDIs in our analyses. In addition, DDIs involving common chemotherapy regimens (e.g., prednisone and docetaxel) were not included in our analyses. Instances of co-administration of multiple proton pump inhibitors were also not considered as DDIs.

We defined "serious DDIs" as DDI pairs with sensitive substrate drugs that have one or more of the following: 1) a narrow therapeutic index, 2) indications as cancer treatments, or 3) an association with significant adverse drug reactions (see bolded drugs in Table S2). 


\section{Composite Precision Medicine Analyses}

The prevalence of CYP inhibitor-mediated phenoconversion was assessed for CYP2B6, CYP2C19, CYP2C9, CYP2D6, and CYP3A4. Within our analyses, we coded subjects as ultrarapid, rapid, normal, or intermediate metabolizers and (2) prescribed a relevant strong CYP inhibitor at any time after first cancer diagnosis.

\section{Statistical Analyses}

Data for the PGx and DDI analyses were analyzed using descriptive statistics (counts and 219 percentages) using JMP Pro v.15.0.0.

\section{RESULTS}

\section{Subject Demographic, Clinical, and Medication Data}

Demographic and clinical characteristics of the 481 study subjects with advanced cancer

224 included are shown in Table 1. Our cohort was a median of $57 \pm 16.6$ (median \pm interquartile

225 range $[\mathrm{IQR}])$ years old, and most subjects were white $(87.9 \%)$ and female $(53.2 \%)$. The most

226 common types of cancer at first diagnosis included breast (12.7\%), pancreatic (10.8\%), and

227 colorectal (9.6\%). The median duration of follow-up, defined as the time between the date of

228 first cancer diagnosis and the date of last prescription, was $2.9 \pm 4.9$ (median $\pm \mathrm{IQR}$ ) years.

229 Extracted medication data contained $\geq 1$ prescription for 469 out of $481(97.5 \%)$ subjects.

230 Filtering to include only prescriptions since each subject's respective date of first cancer 
medRxiv preprint doi: https://doi.org/10.1101/2021.08.23.21262496; this version posted August 30, 2021. The copyright holder for this preprint (which was not certified by peer review) is the author/funder, who has granted medRxiv a license to display the preprint in perpetuity.

All rights reserved. No reuse allowed without permission.

232 analyses (schematic of filtering results shown in Figure S1). Since first cancer diagnosis, our

233 cohort had 1) a total of 7,074 unique prescriptions for medications contained within a CPIC

234 guideline (herein called "PGx medications") and 2) a total of 22,642 unique prescriptions for

235 medications that were defined as inducers, inhibitors, or sensitive substrates of CYP2B6,

236 CYP2C19, CYP2C8, CYP2C9, CYP2D6, and/or CYP3A, acid reducers, or TKIs (herein called

237 "DDI medications").

PGx Analyses

The distribution of genotype-predicted phenotypes within our cohort for all

241 pharmacogenes is displayed in Table 2. When defining actionable phenotypes as those with

242 clinically actionable recommendations within CPIC guidelines for at least one medication, the

243 rates of actionable phenotypes were highest for CYP2C19 (59.5\%) and VKORC1 (52.4\%) and

244 lowest for TPMT (7.3\%), G6PD (1.5\%), and DPYD (1.0\%).

Of 469 analyzed subjects, $282(60.1 \%)$ were prescribed at least one PGx medication.

246 These included a total of 1,045 unique PGx medications (i.e., prescription of a unique PGx

247 medication for a unique subject), with an average of $2.2 \pm 2.4$ (mean \pm standard deviation) PGx

248 medications/subject and a maximum of 12 PGx medications in one subject. When considering

249 both prescribed medications and genotype-predicted phenotypes, we identified a total of 81

250 unique opportunities for "actionable PGx," defined as an instance where a PGx medication was

251 prescribed to a subject with an actionable phenotype based on CPIC recommendations. Instances

252 of actionable PGx occurred for 67 subjects (14.3\%), with 56 subjects having instances of

253 actionable PGx involving 1 medication, 8 subjects having actionable PGx involving 2

254 medications, and 3 subjects having actionable PGx involving 3 medications. 
medRxiv preprint doi: https://doi.org/10.1101/2021.08.23.21262496; this version posted August 30, 2021. The copyright holder for this preprint (which was not certified by peer review) is the author/funder, who has granted medRxiv a license to display the preprint in perpetuity.

All rights reserved. No reuse allowed without permission.

The prevalence of instances of actionable PGx, when stratified by the drug-gene pairs

256

257

258

259

260

261

262

263

264

265

266

267

268

269

270

271

272

273

274

275

276

277

involved, are shown in Table 3. For PGx medications prescribed in at least five subjects, the

rates of actionable PGx were highest for warfarin (87.5\%), amitriptyline (58.3\%), and

clopidogrel (42.9\%). Conversely, capecitabine, 5-fluorouracil, sertraline, and celecoxib had no

instances for actionable PGx. For warfarin, subjects had actionable PGx recommendations based

on $C Y P 2 C 9, C Y P 4 F 2$, and $V K O R C 1$ genotype-based phenotypes in $20.8 \%, 58.3 \%$, and $50.0 \%$ of

cases, respectively. For amitriptyline, subjects had actionable PGx recommendations based on

CYP2C19 and CYP2D6 genotype-based phenotypes in $16.7 \%$ and $50.0 \%$ of cases, respectively.

\section{DDI Analyses}

Of 469 analyzed subjects, the prevalence of $\geq 1$ prescription for an inducer, inhibitor, or substrate of any CYP enzyme was 49.0\%, 58.0\%, and 64.0\%, respectively. Figure S2 displays the prevalence of subjects with prescriptions for inducers, inhibitors, and substrates across the six enzyme systems that were assessed. Prescriptions for CYP inducers were most common for CYP2C19, CYP2C9, and CYP3A, occurring in 49.0\% of subjects. Prescriptions for inhibitors were most common for CYP2D6 (occurring in 53.3\% of subjects), CYP2C9 (35.0\%), CYP3A (33.9\%), and CYP2C19 (31.8\%), while prescriptions for sensitive substrates were most common for CYP3A, CYP2D6, and CYP2C19 (prescribed in 60.3\%, 59.9\%, and 48.2\% of subjects, respectively).

When assessing concomitant prescription of both a relevant perpetrator (inducer or inhibitor) and victim (sensitive substrate) drug, 236 subjects (50.3\%) had a DDI affecting at least one CYP enzyme system. Given the frequent use of corticosteroids to treat and manage treatment-related complications for many types of cancer, ${ }^{27}$ we also performed DDI analyses 
medRxiv preprint doi: https://doi.org/10.1101/2021.08.23.21262496; this version posted August 30, 2021. The copyright holder for this preprint (which was not certified by peer review) is the author/funder, who has granted medRxiv a license to display the preprint in perpetuity.

All rights reserved. No reuse allowed without permission.

278

279

280

281

282

283

284

285

286

287

288

289

290

291

292

293

294

295

296

297

298

299

300

excluding corticosteroids, which are potent inducers of CYP2C19, CYP2C9, and CYP3A; 225

subjects $(48.0 \%)$ had a DDI affecting at least one major CYP enzyme when excluding

corticosteroids. As shown in Table 4, the prevalence of DDIs in our cohort was highest for

CYP2D6 (affecting 45.2\% of subjects; average of 1.5 DDIs/subject), followed by CYP3A

(29.9\%; 0.8 DDIs/subject), CYP2C19 (23.9\%; 0.5 DDIs/subject), CYP2C9 (11.7\%; 0.2

DDIs/subject), CYP2B6 (0.2\%), and CYP2C8 (0\%). When excluding corticosteroids, the

prevalence of DDIs for CYP2C19, CYP2C9, and CYP3A was reduced to 10.2\%, 7.0\%, and

20.3\%, respectively (Table 4). The most common drug-drug pairs contained within observed

DDIs, stratified by enzyme, are shown in Table S4. The subject-level prevalence for serious

DDIs, which were classified by the substrates involved, was $34.8 \%$ for any CYP enzyme when

including corticosteroids and $29.4 \%$ when excluding corticosteroids (Table 4). Serious DDIs

were most common for CYP3A, occurring in $24.9 \%$ of subjects and including sensitive

substrates like fentanyl, midazolam, and tramadol. In contrast, serious DDIs were less common

for CYP2C19 (11.7\% of subjects; sensitive substrates included escitalopram, sertraline, and

citalopram), CYP2C9 (4.7\% of subject; substrates included warfarin, dronabinol, and phenytoin),

and CYP2D6 (16.8\% of subject; substrates included tramadol, sertraline, and mirtazapine).

When adjusting the prevalence of CYP enzyme-mediated DDIs based on subject genotype (i.e.,

excluding DDIs involving inducer or inhibitor drugs in subjects who are genotype-predicted poor

metabolizers), the subject-level prevalence is as follows: CYP2B6: 0.2\%; CYP2C19: 23.9\%;

CYP2C8: 0\%; CYP2C9: 11.7\%; CYP2D6: 44.1\%; and CYP3A: 29.6\% (adjusted based on

CYP3A4 genotype).

TKIs have emerged as first-line treatment options for a variety of cancers. However, multiple investigations have described the potential for significant DDIs involving orally- 
medRxiv preprint doi: https://doi.org/10.1101/2021.08.23.21262496; this version posted August 30, 2021. The copyright holder for this preprint (which was not certified by peer review) is the author/funder, who has granted medRxiv a license to display the preprint in perpetuity.

All rights reserved. No reuse allowed without permission.

administered TKIs and acid reducing agents, including antacids, H2RAs, and PPIs, that reduce TKI bioavailability and impact treatment outcomes. ${ }^{28-31}$ Accordingly, we characterized the prevalence of DDIs involving TKIs and acid reducers in our study population. Within our cohort, 68 subjects (14.5\%) were prescribed at least one TKI, with pazopanib (prescribed in 17 subjects), sunitinib (10), and crizotinib (9) being the most commonly prescribed. Of the 68 subjects prescribed a TKI, $33(48.5 \%)$ had a concomitant prescription of at least one acid reducer. Within our population, the most common acid reducer classes involved in DDIs were PPIs (perpetrator drug in 34 DDIs), followed by H2RAs (10) and antacids (6).

\section{Composite Precision Medicine Analyses}

To assess the prevalence of composite opportunities for precision medicine interventions, we aggregated findings from our actionable PGx, serious CYP-mediated DDI, and acid reducerTKI DDI analyses at the subject level. As shown in Figure 1, 186 subjects (39.7\%) had at least one opportunity for a precision medicine intervention. 68 subjects $(14.5 \%)$ had opportunities for more than one type of precision medicine intervention, with 9 of these subjects $(1.9 \%)$ having opportunities for PGx and management of both CYP-mediated and acid reducer-TKI DDIs. Finally, we assessed the prevalence of CYP inhibitor-mediated phenoconversion, the process by which co-administration of a strong inhibitor functionally converts those with any genotype to a poor metabolizer phenotype, for CYP2B6, CYP2C19, CYP2C9, CYP2D6, and CYP3A4. As shown in Figure 2, CYP inhibitor-mediated phenoconversion enhanced the number of subjects with actionable phenotypes for CYP2C19, CYP2C9, and CYP2D6, and CYP3A4, increasing the prevalence from $59.5 \%$ to $72.8 \%, 33.3 \%$ to $55.9 \%, 44.7 \%$ to $76.3 \%$, and $8.9 \%$ to $38.9 \%$, respectively. In contrast, CYP inhibitor-mediated phenoconversion only 
medRxiv preprint doi: https://doi.org/10.1101/2021.08.23.21262496; this version posted August 30, 2021. The copyright holder for this preprint (which was not certified by peer review) is the author/funder, who has granted medRxiv a license to display the preprint in perpetuity.

All rights reserved. No reuse allowed without permission.

324 slightly changed the number of actionable phenotypes for CYP2B6 (prevalence increased from

$32548.4 \%$ to $49.1 \%$ ) due to the low prevalence of prescription of CYP2B6 inhibitors within our

326 cohort. When considering all five investigated CYPs together, nearly every subject in our cohort

$327(98.3 \%)$ had an actionable phenotype (either genotype-predicted or from CYP inhibitor-mediated

328 phenoconversion) for at least one CYP since their date of first cancer diagnosis. Also, 47

329 subjects $(9.8 \%)$ had genotype-predicted or phenoconverted actionable phenotypes for all five

330 CYP enzymes.

\section{DISCUSSION}

In this investigation, we provide quantitative evidence to support the immense clinical

334 opportunities for precision medicine approaches, including germline PGx and management of

335 DDIs, in a cohort of patients with advanced cancer. Our findings indicate that $\sim 14 \%$ of subjects

336 had opportunities for actionable PGx (i.e., prescription of a PGx medication to a subject with a

337 CPIC guideline-defined actionable genotype) and that $\sim 35 \%$ and $\sim 7 \%$ of subjects had a serious

338 DDI involving major CYP enzymes and acid reducers co-prescribed with TKIs, respectively.

339 When incorporating both PGx and DDIs, we found that $\sim 40 \%$ of subjects had at least one

340 opportunity for a precision medicine-based intervention and nearly all subjects ( 98\%) had an

341 actionable phenotype (genetically-predicted or drug-induced) for $\geq 1 \mathrm{CYP}$ enzyme. Based on our

342 findings, implementation of precision medicine approaches at first cancer diagnosis is likely to

343 provide clinical benefit to a significant proportion of patients. Although a limited number of

344 other studies have addressed similar topics, our investigation has significant methodological

345 advantages, including 1) a larger cohort $(n=481), 2)$ a broader PGx analysis consisting of 13 
medRxiv preprint doi: https://doi.org/10.1101/2021.08.23.21262496; this version posted August 30, 2021. The copyright holder for this preprint (which was not certified by peer review) is the author/funder, who has granted medRxiv a license to display the preprint in perpetuity.

All rights reserved. No reuse allowed without permission.

CPIC-actionable pharmacogenes, and 3) utilization of a statewide data repository to enable more comprehensive collection of medication data.

Previous investigations have demonstrated the potential clinical impact of PGx approaches in patients with advanced cancer. Nichols, et al. catalogued medications in a cohort of 193 patients with advanced cancer, demonstrating that $65 \%$ of patients were taking at least one PGx medication (i.e., those with a CPIC guideline) ${ }^{32}$ Using population estimates of allele frequencies, the authors predicted that $7.1 \%$ of patients in their cohort could benefit from at least one PGx intervention involving medications associated with nine major pharmacogenes:

CYP2C19, CYP2C9, CYP2D6, CYP3A5, CYP4F2, DPYD, HLA-B, SLCO1B1, VKORC1 .

Similarly, Hertz, et al. found that $2.6 \%$ of 115 adult and pediatric patients with cancer could have benefitted from a PGx intervention involving substrates of their analyzed drug-metabolizing enzymes, which included CYP2C19, DPYD, and TPMT. ${ }^{33}$ An investigation by Kasi, et al. also predicted abundant opportunities for PGx interventions within their cohort of 155 patients with advanced cancer based on patient genotypes for major CYP450 enzymes, though they did not specifically collect and analyze medication data. ${ }^{34}$ Many of our findings are similar to those reported in past investigations. For instance, our findings related to the prevalence of prescription of PGx medications are remarkably similar to results from Nichols, et al. when considering both prescription of any PGx medication ( $\sim 60 \%$ in our analysis vs. $65 \%$ in their study) and prescription of specific PGx drugs such as ondansetron, capecitabine, and simvastatin. ${ }^{32}$ Our findings related to the distribution of actionable phenotypes are also consistent with those from past investigations $\mathrm{s}^{32,34}$ as well as those predicted from large analyses of population allele frequencies. ${ }^{35}$ In contrast, our finding for the prevalence of subjects with potential PGx interventions (14.3\%) is higher than those reported by Nichols, et al. (7.1\%) or Hertz, et al. 
medRxiv preprint doi: https://doi.org/10.1101/2021.08.23.21262496; this version posted August 30, 2021. The copyright holder for this preprint (which was not certified by peer review) is the author/funder, who has granted medRxiv a license to display the preprint in perpetuity.

All rights reserved. No reuse allowed without permission.

$369(2.6 \%) \cdot{ }^{32,33}$ These differences are likely attributable to the facts that we (1) investigated the 370 potential for PGx interventions across a wider array of pharmacogenes and (2) that we utilized a

371 statewide repository with prescription data from 38 health systems to enhance the richness of our 372 collected medication data.

374 strategies in adult patients with advanced cancer. A 2009 review by Riechelmann, et al.

375 summarized the prevalence of potential DDIs from six studies, finding rates between $27 \%$ and

$37672 \% .^{36}$ The high variability they observed among studies is likely attributable to differences in 377 employed methodologies (e.g., utilizing patient-verified medication lists versus all drugs listed in

378 EHRs, focusing on all potential drug interactions versus only those involving cancer

379 medications). More recently, investigations within the U.S. and abroad have characterized the 380 prevalence of potential DDIs in cancer patients, finding rates of 40-78\%. ${ }^{37-41}$ Again, it appears

381 that observed differences in potential DDI prevalence are due to methodological differences

382 among the studies. For instance, we found that studies that included DDIs based on both

383 pharmacokinetic (i.e., concomitant administration of an inhibitor or inducer of a drugmetabolizing enzyme along with a sensitive substrate of that enzyme) and pharmacodynamic

385 (i.e., concomitant administration of two or more drugs with the same adverse event profile)

386 mechanisms had higher rates of potential DDIs. ${ }^{38,39}$ Similarly, studies that utilized medication

387 lists taken from the EHR (rather than those verified by patients during medication reconciliation)

388 had higher potential DDI prevalence..$^{38,39}$ The overall DDI prevalence of $\sim 52 \%$ in our study falls 389 in the middle of those reported by past investigations. In terms of methodology, extracting medication data from the EHR likely resulted in a higher DDI prevalence in our study relative to

391 those that used patient-verified medications. We attempted to control for this by utilizing 
medRxiv preprint doi: https://doi.org/10.1101/2021.08.23.21262496; this version posted August 30, 2021. The copyright holder for this preprint (which was not certified by peer review) is the author/funder, who has granted medRxiv a license to display the preprint in perpetuity.

All rights reserved. No reuse allowed without permission.

392

393

394

395

396

397

398

prescription dates to only identify potential DDIs when there was temporal overlap in the prescription (and presumed coadministration) of perpetrator and victim drugs for the same CYP enzyme. Relative to other studies, our DDI prevalence was likely more conservative based on other elements in our methodology, including (1) that we excluded DDIs with pharmacodynamic mechanisms and (2) that we excluded DDIs involving drugs commonly co-administered as cancer treatment regimens (e.g., corticosteroids co-administered with docetaxel or vincristine).

Our rationale for excluding these DDIs was that, in the case of pharmacodynamic DDIs, coadministration of drugs with similar adverse event profiles is often clinically indicated (e.g., dual antiplatelet therapy) and, in the case of DDIs within established cancer regimens, treating clinicians are familiar with these DDIs and have likely already determined a favorable riskbenefit ratio for the patient before prescribing. Therefore, based on these methodological elements, we believe our findings represent a conservative estimate of the prevalence of potential DDIs in advanced cancer patients involving major CYP enzymes. Additionally, our study expands on past investigations assessing potential DDI prevalence in a few significant ways. First, our results stratified DDI prevalence by the CYP enzymes involved, which could aid clinicians in selecting drugs with metabolic pathways less likely to be associated with DDIs. Next, we specifically investigated the prevalence of DDIs for acid reducing agents and TKIs, which has emerged as an important consideration in cancer precision medicine. ${ }^{42}$ Finally, we performed both a composite subject-level analysis and CYP inhibitor-mediated phenoconversion analysis to elucidate the net prevalence of precision medicine opportunities in our study cohort that incorporate both PGx and DDI management approaches.

Our findings are impactful since they demonstrate the abundant clinical opportunities for precision medicine approaches to optimize medication therapy in patients with advanced cancer. 
medRxiv preprint doi: https://doi.org/10.1101/2021.08.23.21262496; this version posted August 30, 2021. The copyright holder for this preprint (which was not certified by peer review) is the author/funder, who has granted medRxiv a license to display the preprint in perpetuity.

All rights reserved. No reuse allowed without permission.

415 Specifically, we found that $\sim 60 \%$ of subjects in our cohort were prescribed at least one PGx

416 medication and that approximately 1 in 7 subjects had an opportunity for actionable PGx since

417 their date of first cancer diagnosis. These findings directly support the clinical utility of PGx

418 approaches in patients with cancer, including the suggestion of preemptive genotyping at first

419 cancer diagnosis. ${ }^{22}$ Advances in technology have also improved the feasibility of PGx

420 approaches by reducing the costs associated with obtaining genetic information and enabling

421 repurposing of genetic information obtained from molecular tumor boards. ${ }^{24}$ In addition,

422 economic analyses have demonstrated cost savings due to toxicity sparing for both $D P Y D$ and

423 TPMT testing. ${ }^{43,44}$ As a result, there is clinical momentum for standardized testing of PGx

424 markers associated with fluoropyrimidine and thiopurine chemotherapies. ${ }^{45,46}$ Our findings also

425 corroborate those from other studies ${ }^{32,34}$ in identifying significant opportunities for PGx to

426 optimize supportive care therapies in patients with cancer, including SSRIs, TCAs, opioids, and

427 commonly used antiemetics (e.g., ondansetron), based on CPIC guidelines. ${ }^{19-21,47}$

428 Related to the clinical opportunities for DDI management strategies, we found that

429 slightly over half of our study subjects had a DDI affecting at least one major CYP enzyme since

430 first cancer diagnosis. This finding is important given that DDIs have been associated with poor

431 clinical outcomes and increased adverse drug events in cancer patients. For instance, CYP-

432 mediated DDIs have been shown to increase the rates of adverse events attributable to both

433 cancer therapies (e.g., increased paclitaxel-induced peripheral neuropathy during co-treatment

434 with clopidogrel) ${ }^{48}$ and concomitant medications (e.g., increased warfarin-induced bleeding

435 during co-treatment with capecitabine $)^{49}$ in patients with cancer. Additionally, several studies

436 have investigated the potential for DDIs between acid reducing agents and TKIs, demonstrating

437 reduced progression-free and overall survival during concomitant therapy attributed to reduced 
medRxiv preprint doi: https://doi.org/10.1101/2021.08.23.21262496; this version posted August 30, 2021. The copyright holder for this preprint (which was not certified by peer review) is the author/funder, who has granted medRxiv a license to display the preprint in perpetuity.

All rights reserved. No reuse allowed without permission.

438 TKI systemic absorption. ${ }^{28-30}$ Our findings support the potential for clinically significant DDIs

439 between acid reducers and TKIs since we observed that these DDIs occurred in nearly half of

440 subjects that were prescribed a TKI. However, it is possible that the providers told the patient to

441 discontinue the acid reducers while taking the TKI's. Nonetheless, our findings support the

442 clinical potential of DDI management strategies, which have been shown to improve outcomes in

443 other populations, ${ }^{9}$ in patients with advanced cancer. Finally, our work serves as one of the first

444 investigations to assess the prevalence of potential drug-drug-gene interactions (DDGIs) (i.e.,

445 CYP inhibitor-mediated phenoconversion) within a clinical cohort. While the strategies to

446 manage DDGIs borrow from both PGx and DDI management approaches, consideration of

447 DDGIs may provide critical information that modifies the risk of adverse drug events predicted

448 from consideration of either approach in isolation. ${ }^{50}$ As demonstrated by our composite study

449 findings that $\sim 40 \%$ of subjects had at least one opportunity for precision medicine intervention

450 and $\sim 98 \%$ of subjects had an actionable phenotype for $\geq 1$ CYP enzymes, PGx information and

451 concomitant drug lists should be used in tandem to most accurately inform approaches to

452 optimize medication therapy. Given the complexities of DDGIs, including concepts like

453 phenoconversion and interplay of multiple drug biotransformation pathways, expert guidance

454 that includes perspectives from both clinical pharmacologists and clinicians is needed to inform

455 actionable clinical management strategies.

We acknowledge several limitations of our study. First, our extracted medication data did

457 not include a way to conclusively ascertain days supply in order to assess temporal overlap

458 between perpetrator and victim drugs within our DDI analyses. To compensate for this

459 limitation, we used conservative methods in our DDI analyses to estimate days supply for each

460 prescription, as described in the methods. While this limitation may have influenced our findings 
medRxiv preprint doi: https://doi.org/10.1101/2021.08.23.21262496; this version posted August 30, 2021. The copyright holder for this preprint (which was not certified by peer review) is the author/funder, who has granted medRxiv a license to display the preprint in perpetuity.

All rights reserved. No reuse allowed without permission.

461 related to the prevalence of DDIs, it did not impact results from our PGx analyses. Our extracted

462 medication data also did not consistently contain information about the medication dose. As a

463 result, our analysis may have overestimated the prevalence of instances for actionable PGx with

464 amitriptyline since current CPIC guidelines do not recommend clinical action at daily doses

465 under $50 \mathrm{mg} .{ }^{19}$ Also, our panel-based genotyping method only tested for relatively common

466 functional variants in the assessed genes within our primary ethnic and racial populations,

467 potentially excluding rare functional variants that alter drug response. While we do not expect

468 that this approach significantly impacted our findings, it is important to note that utilizing panel-

469 based genotyping (as opposed to a more complete approach like whole genome sequencing) may

470 have caused us to underestimate the actual clinical opportunities for actionable PGx in our

471 cohort. Additionally, advances in knowledge since study initiation limited our ability to assess

472 variants with newly established relevance to pharmacotherapy (e.g., HapB3 in DPYD).Our

473 genotyping panel also did not assess every pharmacogene included within a CPIC guideline.

474 However, the pharmacogenes covered in our panel serve as the genetic basis for over $80 \%$ of the

475 PGx recommendations contained within current CPIC guidelines. 5

476 In conclusion, our work provides quantitative evidence of the vast clinical opportunities

477 for precision medicine approaches in patients with advanced cancer, demonstrating the clinical

478 utility of both germline PGx and DDI management strategies. Given their established clinical

479 benefits and the abundant opportunities for their use demonstrated by our results, precision

480 medicine approaches are likely to improve medication outcomes in cancer patients and may

481 provide clinical benefit if incorporated into the workflow of molecular tumor boards. In order to

482 facilitate widespread adoption of precision medicine approaches in this high-value patient

483 population, future research is needed to (1) prospectively demonstrate the clinical benefit of 
medRxiv preprint doi: https://doi.org/10.1101/2021.08.23.21262496; this version posted August 30, 2021. The copyright holder for this preprint (which was not certified by peer review) is the author/funder, who has granted medRxiv a license to display the preprint in perpetuity.

All rights reserved. No reuse allowed without permission.

484 precision medicine approaches on patient outcomes and to (2) identify effective strategies for

485 clinical implementation of precision medicine approaches.

486

487 ACKNOWLEDGEMENTS

488 None 
medRxiv preprint doi: https://doi.org/10.1101/2021.08.23.21262496; this version posted August 30, 2021. The copyright holder for this preprint (which was not certified by peer review) is the author/funder, who has granted medRxiv a license to display the preprint in perpetuity. All rights reserved. No reuse allowed without permission.

\section{REFERENCES}

1. Claassens DMF, Vos GJA, Bergmeijer TO, et al: A Genotype-Guided Strategy for Oral P2Y(12) Inhibitors in Primary PCI. N Engl J Med 381:1621-1631, 2019

2. Mallal S, Phillips E, Carosi G, et al: HLA-B*5701 screening for hypersensitivity to abacavir. N Engl J Med 358:568-79, 2008

3. Pirmohamed M, Burnside G, Eriksson N, et al: A randomized trial of genotype-guided dosing of warfarin. N Engl J Med 369:2294-303, 2013

4. U.S. Food and Drug Administration: Table of Pharmacogenomic Biomarkers in Drug Labeling, (ed 08/18/20), 2020

5. Clinical Pharmacogenetics Implementation Consortium: Guidelines, 2020

6. Shugg T, Pasternak AL, London B, et al: Prevalence and types of inconsistencies in clinical pharmacogenetic recommendations among major U.S. sources. NPJ Genom Med 5:48, 2020

7. Bates DW, Cullen DJ, Laird N, et al: Incidence of adverse drug events and potential adverse drug events. Implications for prevention. ADE Prevention Study Group. Jama 274:29-34, 1995

8. Wright A, Feblowitz J, Phansalkar S, et al: Preventability of adverse drug events involving multiple drugs using publicly available clinical decision support tools. Am J Health Syst Pharm 69:221-7, 2012

9. Arnold RJG, Tang J, Schrecker J, et al: Impact of Definitive Drug-Drug Interaction Testing on Medication Management and Patient Care. Drugs Real World Outcomes 5:217-224, 2018

10. U.S. Food and Drug Administration: Clinical Drug Interaction Studies -- Cytochrome P450 Enzyme- and Transporter-Mediated Drug Interactions: Guidance for Industry, (ed January 2020), 2020

11. Department of Health and Human Services Office of AIDS Research Advisory Council: Guidelines for the Use of Antiretroviral Agents in Adults and Adolescents with HIV, 2018

12. Grundy SM, Stone NJ, Bailey AL, et al: 2018 AHA/ACC/AACVPR/AAPA/ABC/ACPM/ADA/AGS/APhA/ASPC/NLA/PCNA Guideline on the Management of Blood Cholesterol: A Report of the American College of Cardiology/American Heart Association Task Force on Clinical Practice Guidelines. Circulation 139:e1082-e1143, 2019

13. LeBlanc TW, McNeil MJ, Kamal AH, et al: Polypharmacy in patients with advanced cancer and the role of medication discontinuation. Lancet Oncol 16:e333-41, 2015

14. Guthrie B, Makubate B, Hernandez-Santiago V, et al: The rising tide of polypharmacy and drug-drug interactions: population database analysis 1995-2010. BMC Med 13:74, 2015

15. Sharma M, Vadhariya A, Chikermane S, et al: Clinical Outcomes Associated with DrugDrug Interactions of Oral Chemotherapeutic Agents: A Comprehensive Evidence-Based Literature Review. Drugs Aging 36:341-354, 2019

16. Kato S, Kim KH, Lim HJ, et al: Real-world data from a molecular tumor board demonstrates improved outcomes with a precision N-of-One strategy. Nat Commun 11:4965, 2020

17. Relling MV, Schwab M, Whirl-Carrillo M, et al: Clinical Pharmacogenetics Implementation Consortium Guideline for Thiopurine Dosing Based on TPMT and NUDT15 Genotypes: 2018 Update. Clin Pharmacol Ther 105:1095-1105, 2019

18. Amstutz U, Henricks LM, Offer SM, et al: Clinical Pharmacogenetics Implementation Consortium (CPIC) Guideline for Dihydropyrimidine Dehydrogenase Genotype and Fluoropyrimidine Dosing: 2017 Update. Clin Pharmacol Ther 103:210-216, 2018 
19. Hicks JK, Sangkuhl K, Swen JJ, et al: Clinical pharmacogenetics implementation consortium guideline (CPIC) for CYP2D6 and CYP2C19 genotypes and dosing of tricyclic antidepressants: 2016 update. Clin Pharmacol Ther 102:37-44, 2017

20. Crews KR, Gaedigk A, Dunnenberger HM, et al: Clinical Pharmacogenetics Implementation Consortium guidelines for cytochrome P450 2D6 genotype and codeine therapy: 2014 update. Clin Pharmacol Ther 95:376-82, 2014

21. Hicks JK, Bishop JR, Sangkuhl K, et al: Clinical Pharmacogenetics Implementation Consortium (CPIC) Guideline for CYP2D6 and CYP2C19 Genotypes and Dosing of Selective Serotonin Reuptake Inhibitors. Clin Pharmacol Ther 98:127-34, 2015

22. Hoffman JM, Haidar CE, Wilkinson MR, et al: PG4KDS: a model for the clinical implementation of pre-emptive pharmacogenetics. Am J Med Genet C Semin Med Genet $166 \mathrm{c}: 45-55,2014$

23. van der Lee M, Allard WG, Bollen S, et al: Repurposing of Diagnostic Whole Exome Sequencing Data of 1,583 Individuals for Clinical Pharmacogenetics. Clin Pharmacol Ther 107:617-627, 2020

24. Numanagić I, Malikić S, Ford M, et al: Allelic decomposition and exact genotyping of highly polymorphic and structurally variant genes. Nat Commun 9:828, 2018

25. U.S. Food and Drug Administration: Drug Development and Drug Interactions: Table of Substrates, Inhibitors and Inducers, (ed 03/10/20), 2020

26. Indiana University School of Medicine: Drug Interactions Flockhart Table, 2020

27. Lossignol D: A little help from steroids in oncology. J Transl Int Med 4:52-54, 2016

28. Chen YM, Lai CH, Chang HC, et al: Antacid Use and De Novo Brain Metastases in Patients with Epidermal Growth Factor Receptor-Mutant Non-Small Cell Lung Cancer Who Were Treated Using First-Line First-Generation Epidermal Growth Factor Receptor Tyrosine Kinase Inhibitors. PLoS One 11:e0149722, 2016

29. Chu MP, Ghosh S, Chambers CR, et al: Gastric Acid suppression is associated with decreased erlotinib efficacy in non-small-cell lung cancer. Clin Lung Cancer 16:33-9, 2015

30. Ha VH, Ngo M, Chu MP, et al: Does gastric acid suppression affect sunitinib efficacy in patients with advanced or metastatic renal cell cancer? J Oncol Pharm Pract 21:194-200, 2015

31. Mir O, Touati N, Lia M, et al: Impact of Concomitant Administration of Gastric AcidSuppressive Agents and Pazopanib on Outcomes in Soft-Tissue Sarcoma Patients Treated within the EORTC 62043/62072 Trials. Clin Cancer Res 25:1479-1485, 2019

32. Nichols D, Arnold S, Weiss HL, et al: Pharmacogenomic potential in advanced cancer patients. Am J Health Syst Pharm 76:415-423, 2019

33. Hertz DL, Glatz A, Pasternak AL, et al: Integration of Germline Pharmacogenetics Into a Tumor Sequencing Program. JCO Precis Oncol 2, 2018

34. Kasi PM, Koep T, Schnettler E, et al: Feasibility of Integrating Panel-Based Pharmacogenomics Testing for Chemotherapy and Supportive Care in Patients With Colorectal Cancer. Technol Cancer Res Treat 18:1533033819873924, 2019

35. Zhou Y, Ingelman-Sundberg M, Lauschke VM: Worldwide Distribution of Cytochrome P450 Alleles: A Meta-analysis of Population-scale Sequencing Projects. Clin Pharmacol Ther 102:688-700, 2017

36. Riechelmann RP, Del Giglio A: Drug interactions in oncology: how common are they? Ann Oncol 20:1907-12, 2009 
medRxiv preprint doi: https://doi.org/10.1101/2021.08.23.21262496; this version posted August 30, 2021. The copyright holder for this preprint (which was not certified by peer review) is the author/funder, who has granted medRxiv a license to display the preprint in perpetuity.

All rights reserved. No reuse allowed without permission.

602

603

604

605

606

607

608

609

610

611

612

613

614

615

616

617

618
37. Chen L, Cheung WY: Potential drug interactions in patients with a history of cancer. Curr Oncol 21:e212-20, 2014

38. Ismail M, Khan S, Khan F, et al: Prevalence and significance of potential drug-drug interactions among cancer patients receiving chemotherapy. BMC Cancer 20:335, 2020

39. Korucu FC, Senyigit E, Köstek O, et al: A retrospective study on potential drug interactions: A single center experience. Journal of Oncological Sciences 4:80-84, 2018

40. van Leeuwen RW, Brundel DH, Neef C, et al: Prevalence of potential drug-drug interactions in cancer patients treated with oral anticancer drugs. Br J Cancer 108:1071-8, 2013

41. van Leeuwen RW, Swart EL, Boven E, et al: Potential drug interactions in cancer therapy: a prevalence study using an advanced screening method. Ann Oncol 22:2334-41, 2011

42. Yu G, Zheng QS, Wang DX, et al: Drug interactions between tyrosine-kinase inhibitors and acid suppressive agents: more than meets the eye. Lancet Oncol 15:e469-70, 2014

43. Zarca K, Durand-Zaleski I, Loriot MA, et al: Modeling the Outcome of Systematic TPMT Genotyping or Phenotyping Before Azathioprine Prescription: A Cost-Effectiveness

Analysis. Mol Diagn Ther 23:429-438, 2019

44. Fragoulakis V, Roncato R, Fratte CD, et al: Estimating the Effectiveness of DPYD Genotyping in Italian Individuals Suffering from Cancer Based on the Cost of Chemotherapy-Induced Toxicity. Am J Hum Genet 104:1158-1168, 2019

45. Weitzel KW, Smith DM, Elsey AR, et al: Implementation of Standardized Clinical Processes for TPMT Testing in a Diverse Multidisciplinary Population: Challenges and Lessons Learned. Clin Transl Sci 11:175-181, 2018

46. Hertz DL, Sahai V: Including DPYD on Cancer Genetic Panels to Prevent Fatal Fluoropyrimidine Toxicity. J Natl Compr Canc Netw 18:372-374, 2020

47. Bell GC, Caudle KE, Whirl-Carrillo M, et al: Clinical Pharmacogenetics Implementation Consortium (CPIC) guideline for CYP2D6 genotype and use of ondansetron and tropisetron. Clin Pharmacol Ther 102:213-218, 2017

48. Agergaard K, Mau-Sørensen M, Stage TB, et al: Clopidogrel-Paclitaxel Drug-Drug Interaction: A Pharmacoepidemiologic Study. Clin Pharmacol Ther 102:547-553, 2017

49. Shah HR, Ledbetter L, Diasio R, et al: A retrospective study of coagulation abnormalities in patients receiving concomitant capecitabine and warfarin. Clin Colorectal Cancer 5:354-8, 2006

50. Malki MA, Pearson ER: Drug-drug-gene interactions and adverse drug reactions. Pharmacogenomics J 20:355-366, 2020 
medRxiv preprint doi: https://doi.org/10.1101/2021.08.23.21262496; this version posted August 30, 2021. The copyright holder for this preprint (which was not certified by peer review) is the author/funder, who has granted medRxiv a license to display the preprint in perpetuity.

All rights reserved. No reuse allowed without permission.

\section{FIGURE LEGENDS}

620 Figure 1. Subject-level prevalence for composite precision medicine opportunities, including

621 actionable PGx, management of serious CYP-mediated DDIs, and management of DDIs

622 including acid reducers and TKIs.

623

624 Figure 2. Subject-level prevalence of clinically actionable phenotypes for major CYP enzymes

625 based on genotype and due to CYP inhibitor-mediated phenoconversion.

626

627

628

629

630

631

632

633

634

635

636

637

638

639

640

641 
TABLES

Table 1. Demographic and clinical characteristics of study cohort with advanced cancer.

\begin{tabular}{|l|c|}
\hline Variable & $\begin{array}{c}\text { Value in Full } \\
\text { Cohort (n=481) }\end{array}$ \\
\hline $\begin{array}{l}\text { Age in years at first cancer } \\
\text { diagnosis (median [IQR]) }\end{array}$ & $57.4(16.6)$ \\
\hline $\begin{array}{l}\text { Sex_(Count [Percent]) } \\
\text { Female } \\
\text { Male }\end{array}$ & $256(53.2 \%)$ \\
\hline Race (Count [Percent]) & $225(46.8 \%)$ \\
White & $423(87.9 \%)$ \\
Black & $38(7.9 \%)$ \\
Asian & $8(1.7 \%)$ \\
Other* & $3(0.4 \%)$ \\
Unknown & $9(1.9 \%)$ \\
\hline Cancer type at first diagnosis & \\
(Count [Percent]) & \\
Breast & $61(12.7 \%)$ \\
Pancreatic & $52(10.8 \%)$ \\
Colorectal & $46(9.6 \%)$ \\
Prostate & $40(8.3 \%)$ \\
Soft-tissue sarcoma & $36(7.5 \%)$ \\
Ovarian & $26(5.4 \%)$ \\
Non-small cell lung & $23(4.8 \%)$ \\
Renal & $18(3.7 \%)$ \\
Thymic & $13(2.7 \%)$ \\
Cholangiocarcinoma & $12(2.5 \%)$ \\
Head and neck & $11(2.3 \%)$ \\
Bladder & $10(2.1 \%)$ \\
Unknown primary & $13(2.7 \%)$ \\
\hline Duration of follow-up in years \\
(median [IQR]) & $2.9(4.9)$ \\
\hline One individuat who repoted & \\
\hline
\end{tabular}

644 *One individual who reported a race of "other" reported Hispanic ethnicity.

$645{ }^{+}$Defined as the time elapsed between the date of first cancer diagnosis and date of most recent 646 prescription 
Table 2. Distribution of genotype-predicted phenotypes within study cohort for major pharmacogenes.

\begin{tabular}{|c|c|c|c|c|c|c|}
\hline Gene & $\begin{array}{c}\text { Ultrarapid } \\
\text { Metabolizer }\end{array}$ & $\begin{array}{c}\text { Normal } \\
\text { Metabolizer }\end{array}$ & $\begin{array}{l}\text { Intermediate } \\
\text { Metabolizer }\end{array}$ & $\begin{array}{c}\text { Poor } \\
\text { Metabolizer }\end{array}$ & Indeterminate & Actionable \\
\hline CYP2B6 & & $248(51.6 \%)$ & $199(41.4 \%)$ & $34(7.1 \%)$ & & $233(48.4 \%)$ \\
\hline CYP2C19 & $153(31.8 \%)^{*}$ & $189(39.3 \%)$ & $124(25.8 \%)$ & $9(1.9 \%)$ & $6(1.2 \%)$ & $286(59.5 \%)$ \\
\hline CYP2C9 & & $321(66.7 \%)$ & $146(30.4 \%)$ & $14(2.9 \%)$ & & $160(33.3 \%)$ \\
\hline CYP2D6 & $9(1.9 \%)$ & $254(52.8 \%)$ & $182(37.8 \%)$ & $24(5.0 \%)$ & $12(2.5 \%)$ & $215(44.7 \%)$ \\
\hline CYP3A4 & & $437(90.9 \%)$ & $41(8.5 \%)$ & $2(0.4 \%)$ & $1(0.2 \%)$ & $43(8.9 \%)^{ \pm}$ \\
\hline CYP3A5 & & $17(3.5 \%)$ & $71(14.8 \%)$ & $391(81.3 \%)$ & $2(0.4 \%)$ & $88(18.3 \%)$ \\
\hline CYP4F2 & & $265(55.1 \%)$ & $175(36.4 \%)$ & $41(8.5 \%)$ & & $216(44.9 \%)$ \\
\hline$D P Y D$ & & $476(99.0 \%)$ & $5(1.0 \%)$ & $0(0 \%)$ & & $5(1.0 \%)$ \\
\hline$G^{\prime} P^{+} D^{+}$ & & $474(98.5 \%)$ & $4(0.8 \%)$ & $3(0.6 \%)$ & & $7(1.5 \%)$ \\
\hline IFNL3 $(\text { IL28B })^{+}$ & & $204(42.4 \%)$ & $220(45.7 \%)$ & $57(11.9 \%)$ & & $0(0 \%)$ \\
\hline $\mathrm{SLCO1B1}^{+}$ & & $333(69.2 \%)$ & $107(22.2 \%)$ & $11(2.3 \%)$ & $30(6.2 \%)$ & $118(24.5 \%)$ \\
\hline TPMT & & $440(91.5 \%)$ & $35(7.3 \%)$ & $0(0 \%)$ & $6(1.2 \%)$ & $35(7.3 \%)$ \\
\hline $\mathrm{VKORC1}^{+}$ & & $229(47.6 \%)$ & $199(41.4 \%)$ & $53(11.0 \%)$ & & $252(52.4 \%)$ \\
\hline
\end{tabular}

*For CYP2C19, count in ultrarapid metabolizer column includes counts of both ultrarapid metabolizers $(\mathrm{n}=20)$ and rapid metabolizers $(\mathrm{n}=133)$.

"For designated genes, "normal metabolizer," "intermediate metabolizer," and "poor metabolizer" designations refer to subjects who are non-carriers, heterozygous, and homozygous for CPIC-defined actionable variants, respectively.

${ }^{ \pm}$While CPIC does not make CYP3A4 genetic-guided recommendations for any drugs, we classify subjects with one or two copies of the $C Y P 3 A 4 * 22$ loss-of-function allele as intermediate and poor metabolizers, respectively, and consider these phenotypes to be actionable since they are used at our institution to guide tacrolimus dosing in CYP3A5 non-expressers. 
Table 3. Prevalence of PGx medications prescribed in subjects with clinically actionable genotype-predicted phenotypes based on CPIC recommendations.

\begin{tabular}{|c|c|c|}
\hline Drug-Gene Pair & \# Prescribed Drug & $\%$ with Actionable PGx \\
\hline Ondansetron- $C Y P 2 D 6$ & 256 & $0.8 \%$ \\
\hline Pantoprazole-CYP2C19 & 171 & $4.7 \%$ \\
\hline Omeprazole-CYP2C19 & 99 & $2.0 \%$ \\
\hline Ibuprofen-CYP2C9 & 93 & $5.4 \%$ \\
\hline Tramadol-CYP2D6 & 81 & $6.2 \%$ \\
\hline Capecitabine-DPYD & 62 & $0 \%$ \\
\hline 5-Fluorouracil-DPYD & 40 & $0 \%$ \\
\hline Sertraline-CYP2C19 & 28 & $0 \%$ \\
\hline Escitalopram-CYP2C19 & 25 & $12.0 \%$ \\
\hline Lansoprazole-CYP2C19 & 24 & $4.2 \%$ \\
\hline Warfarin-CYP2C $9 / C Y P 4 F 2 / V K O R C 1$ & 24 & $87.5 \%$ \\
\hline Citalopram-CYP2C19 & 21 & $23.8 \%$ \\
\hline Simvastatin-SLCO1B1 & 21 & $23.8 \%$ \\
\hline Meloxicam-CYP2C9 & 16 & $12.5 \%$ \\
\hline Celecoxib-CYP2C9 & 15 & $0 \%$ \\
\hline Amitriptyline- $C Y P 2 C 19 / C Y P 2 D 6$ & 12 & $58.3 \%$ \\
\hline Nortriptyline-CYP2D6 & 9 & $11.1 \%$ \\
\hline Dexlansoprazole-CYP2C19 & 8 & $12.5 \%$ \\
\hline Clopidogrel- $C Y P 2 C 19$ & 7 & $42.9 \%$ \\
\hline Codeine- $C Y P 2 D 6$ & 7 & $14.3 \%$ \\
\hline Paroxetine- $C Y P 2 D 6$ & 6 & $16.7 \%$ \\
\hline Tamoxifen-CYP2D6 & 6 & $33.3 \%$ \\
\hline Doxepin-CYP2C19/CYP2D6 & 3 & $100 \%$ \\
\hline Voriconazole-CYP2C19 & 3 & $66.7 \%$ \\
\hline Rasburicase-G6PD & 2 & $0 \%$ \\
\hline Atomoxetine-CYP2D6 & 1 & $0 \%$ \\
\hline Azathioprine-TPMT & 1 & $0 \%$ \\
\hline Imipramine-CYP2C19/CYP2D6 & 1 & $100 \%$ \\
\hline Phenytoin- $C Y P 2 C 9$ & 1 & $0 \%$ \\
\hline Ribavirin-IFNL3 & 1 & $0 \%$ \\
\hline Tacrolimus-CYP3A5 & 1 & $0 \%$ \\
\hline Total & 1045 & \\
\hline
\end{tabular}

The "number prescribed drug" indicates the number of subjects within our cohort that were prescribed the corresponding drug. The "percent with actionable PGx," which was calculated at the subject-level, indicates the percent of subjects prescribed the corresponding drug that had genotypes for which current CPIC guidelines recommend actionable clinical management strategies. 
Table 4. Number and prevalence of unique DDIs (i.e., unique co-prescription of a relevant drug-drug pair in a unique subject) by enzyme involved in $n=469$ subjects prescribed $\geq 1$ medication, including (left) and excluding (right) DDIs involving corticosteroids.

\begin{tabular}{|c|c|c|c|c|c|c|c|c|}
\hline & \multicolumn{3}{|c|}{ DDIs Including Corticosteroids } & \multicolumn{3}{c|}{ DDIs Excluding Corticosteroids } \\
\cline { 2 - 9 } Enzyme & $\begin{array}{c}\text { Total } \\
\text { DDIs }\end{array}$ & $\begin{array}{c}\text { DDIs/Subject } \\
\text { (Mean) }\end{array}$ & $\begin{array}{c}\text { DDI } \\
\text { Prevalence (\%) }\end{array}$ & $\begin{array}{c}\text { Serious DDI } \\
\text { Prevalence (\%) }\end{array}$ & $\begin{array}{c}\text { Total } \\
\text { DDIs }\end{array}$ & $\begin{array}{c}\text { DDIs/Subject } \\
\text { (Mean) }\end{array}$ & $\begin{array}{c}\text { DDI } \\
\text { Prevalence (\%) }\end{array}$ & $\begin{array}{c}\text { Serious DDI } \\
\text { Prevalence (\%) }\end{array}$ \\
\hline CYP2B6 & 1 & 0.00 & $0.2 \%$ & $0.2 \%$ & 1 & 0.00 & $0.2 \%$ & $0.2 \%$ \\
\hline CYP2C19 & 237 & 0.51 & $23.9 \%$ & $11.7 \%$ & 89 & 0.19 & $10.2 \%$ & $5.8 \%$ \\
\hline CYP2C8 & 0 & 0 & $0 \%$ & $0 \%$ & 0 & 0 & $0 \%$ & $0 \%$ \\
\hline CYP2C9 & 76 & 0.16 & $11.7 \%$ & $4.7 \%$ & 39 & 0.08 & $7.0 \%$ & $2.3 \%$ \\
\hline CYP2D6 & 695 & 1.48 & $45.2 \%$ & $16.8 \%$ & 695 & 1.48 & $45.2 \%$ & $16.8 \%$ \\
\hline CYP3A & 392 & 0.84 & $29.9 \%$ & $24.9 \%$ & 217 & 0.46 & $20.3 \%$ & $18.6 \%$ \\
\hline Any DDI & $\mathbf{1 4 0 1}$ & $\mathbf{2 . 9 9}$ & $\mathbf{5 0 . 3 \%}$ & $\mathbf{3 4 . 8 \%}$ & $\mathbf{1 0 4 1}$ & $\mathbf{2 . 2 2}$ & $\mathbf{4 8 . 0 \%}$ & $\mathbf{2 9 . 4 \%}$ \\
\hline
\end{tabular}

Note: All DDI prevalence calculations are at the subject level. 


\section{FIGURES}

Figure 1.

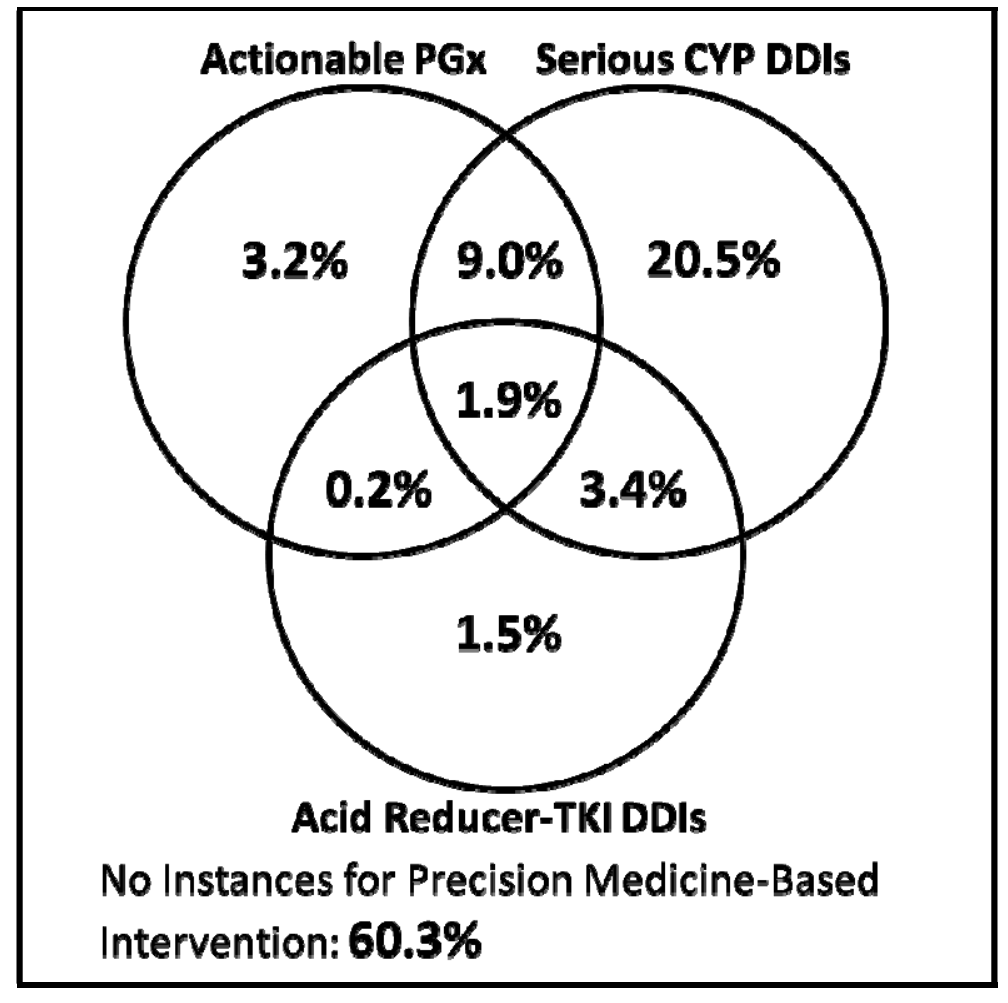


Figure 2.

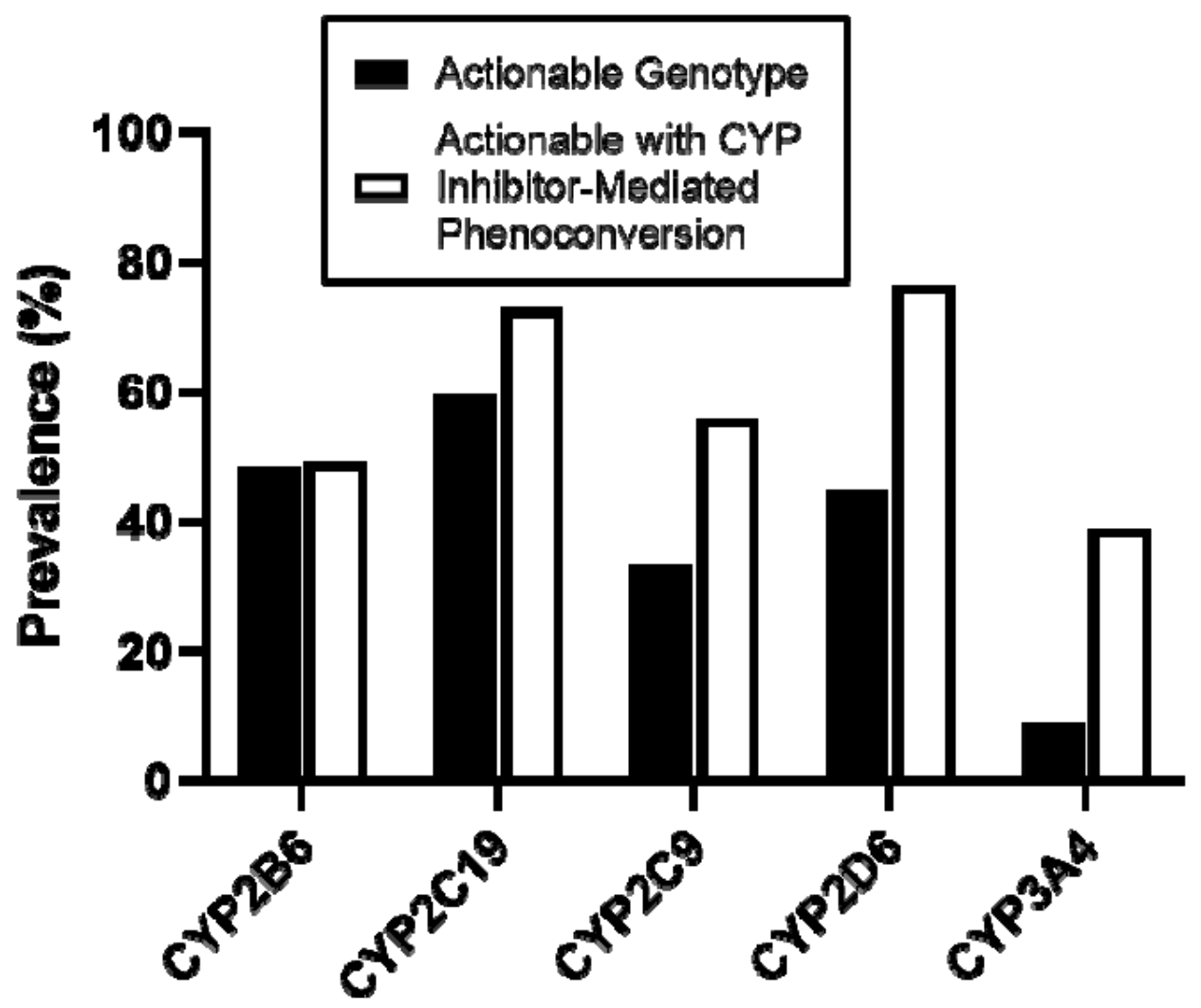

